\title{
Kaposi sarcoma after kidney transplantation
}

\author{
Juliette Raedemaeker, Liliane Marot, Alessandra Camboni, Nada Kanaan
}

Department of Nephrology, Cliniques Universitaires SaintLuc, Bruxelles, Belgium

\section{Correspondence to}

Professor Nada Kanaan, nada.kanaan@uclouvain.be

Accepted 16 April 2019

\section{DESCRIPTION}

A North-African woman in her mid-70s presented with a red-purplish macular rash on her right thigh and left lower limb. The skin lesions had developed over the last 6 months and did not cause pruritus or pain. She had been transplanted with a deceased-donor kidney 5 years ago for diabetic nephropathy. Her treatment included tacrolimus, mycophenolate mofetil (MMF) and low-dose methylprednisolone. Physical examination revealed large cutaneous purplish confluent infiltrative plaques on the anterior left leg and right thigh highly evocative of Kaposi sarcoma (KS) (figure 1A). No ulceration, bleeding or oedema was noted. Regional lymph nodes were not palpated. Laboratory tests were in the usual range. HIV serology was negative. Skin biopsy confirmed the diagnosis of KS: histology revealed the presence of fusiform cells of endothelial origin and neovessels (figure 2A,B), while immunohistochemical staining showed positive labelling for erythroblast transformation-specific related gene (ERG) and human herpes virus type 8 (HHV8) on endothelial cells (figure 2C,D). Positron-emission tomography did not reveal hyper metabolic lesions. Chemotherapy based on pegylated liposomal doxorubicin (PLD), cessation of MMF and a switch from tacrolimus to sirolimus was proposed. The patient declined the treatment and left the country. She came back 1 year later with significant spread of skin lesions (figure 1B). She received five cycles of PLD without improvement, and was quickly readmitted for general weakness, anorexia, epigastralgia, dysphagia and cough. Workout revealed interstitial pneumonitis, esophagitis and gastric ulcer. Bronchoalveolar lavage was not contributive, but immunohistochemistry of the gastric lesion revealed an atypical

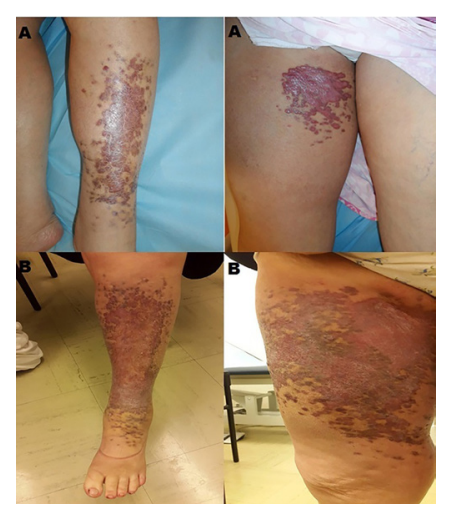

Figure 1 Skin lesions in Kaposi sarcoma. (A) Large cutaneous purplish confluent infiltrative plaques on the anterior left leg and right thigh. (B) Significant spread of skin lesions.

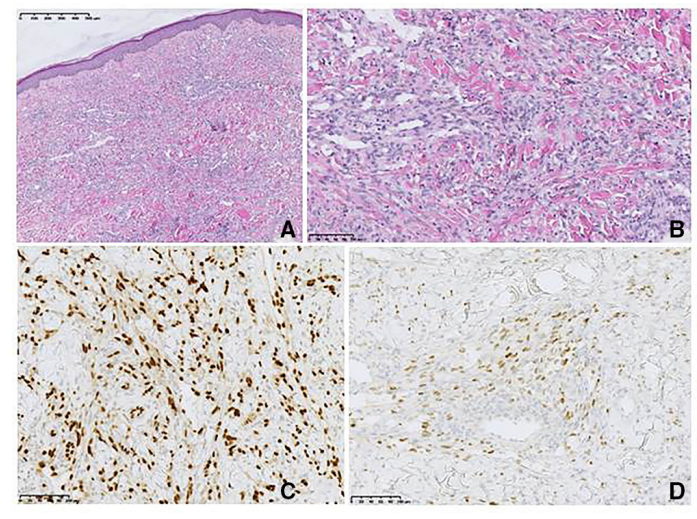

Figure 2 Histological and immunohistochemical features of Kaposi's sarcoma. Histological section showing fusiform cells and neovessels ((A) H\&E $\times 5$ and (B) $H \& E \times 20)$. (C) Erythroblast transformation-specific related gene labelling, endothelial differentiation marker (×20). (D) Positive labelling for HHV8 (×20). HHV8, human herpes virus type 8 .

vascularisation positive for HHV8 and ERG, compatible with KS. The patient became rapidly hypoxic and died.

KS is an angioproliferative cutaneous cancer caused by human herpesvirus $8 .^{1}$ Skin lesions are typical and make the diagnosis. These are purplered-bluish lesions presenting as non-painful, non-itchy, macules, papules, plaques or nodules. Due to their vascular aetiology, they can ulcerate and bleed. The incidence of KS is higher in transplant patients than in non-immunosuppressed populations. In kidney transplant recipients, the intensity and duration of immunosuppression, and the presence of HHV8 serology pretransplantation increase the risk of developing KS, which occurs 13 months after transplantation (range few weeks to 18 years). ${ }^{2}$ Serological testing for HHV8 was unavailable pretransplantation for our patient and the donor, making difficult to ascertain the origin of the infection. However, the Mediterranean origin of the patient where HHV8 seroprevalence is high made her at risk for KS. Lesions usually begin on the lower limbs, with multifocal and asymptomatic

\section{Learning points}

Kidney transplant recipients are at higher risk of Kaposi sarcoma because of immunosuppression and human herpes virus type 8 reactivation.

- Dissemination is common if not treated rapidly and adequately.

- A late diagnosis with visceral involvement has a poor prognosis. 
development. KS may remain localised to the skin, but dissemination to visceral mucosa of the trachea, lungs and gastrointestinal tract is common in immunosuppressed patients. Reduction of immunosuppressive therapy, as well as a switch of calcineurin inhibitor to mammalian target of rapamycin may obtain resolution of disease in the early stages of the disease. ${ }^{3}$ For extensive involvement, liposomal anthracyclines is proposed as a first-line therapy. ${ }^{4}$ Mucosal dissemination or visceral involvement has usually a poor prognosis. ${ }^{2}$ Our patient refusal of treatment for 1 year contributed to the dramatic spread of KS and fatal outcome.

Contributors JR wrote the first draft. LM took care of the patient. AC did the histology analysis. NK took care of the patient and wrote the final draft.
Funding The authors have not declared a specific grant for this research from any funding agency in the public, commercial or not-for-profit sectors.

Competing interests None decared.

Patient consent for publication Not required.

Provenance and peer review Not commissioned; externally peer reviewed.

\section{REFERENCES}

1 Radu O, Pantanowitz L. Kaposi sarcoma. Arch Pathol Lab Med 2013;137:289-94.

2 Euvrard S, Kanitakis J, Claudy A. Skin cancers after organ transplantation. N Engl J Med 2003;348:1681-91

3 Stallone G, Schena A, Infante B, et al. Sirolimus for Kaposi's sarcoma in renal-transplant recipients. N Eng/ I Med 2005;352:1317-23.

4 Di Lorenzo G. Update on classic Kaposi sarcoma therapy: New look at an old disease. Crit Rev Oncol Hematol 2008;68:242-9.

Copyright 2019 BMJ Publishing Group. All rights reserved. For permission to reuse any of this content visit

https://www.bmj.com/company/products-services/rights-and-licensing/permissions/

BMJ Case Report Fellows may re-use this article for personal use and teaching without any further permission.

Become a Fellow of BMJ Case Reports today and you can:

- Submit as many cases as you like

- Enjoy fast sympathetic peer review and rapid publication of accepted articles

- Access all the published articles

Re-use any of the published material for personal use and teaching without further permission

For information on Institutional Fellowships contact consortiasales@bmjgroup.com

Visit casereports.bmj.com for more articles like this and to become a Fellow 